\title{
A review of amber and copal occurrences in Africa and their paleontological significance
}

\author{
Valentine Bouju and Vincent Perrichot ${ }^{*}$ \\ Univ. Rennes, CNRS, Géosciences Rennes, UMR 6118, F35000 Rennes, France
}

Received: 9 April 2020 / Accepted: 19 May 2020

\begin{abstract}
The paleontological interest for fossil plant resins (amber and copal) has greatly increased in the last decades, as field studies have resulted in the discovery of various new deposits worldwide. Yet, amberrich deposits remain particularly scarce on continents from former Gondwana. Here we review the known occurrences of copal and amber from Africa, with a state-of-the-art regarding the age dating, the putative plant sources, the fossil content, as well as the paleoenvironmental settings. The first African ambers known to yield arthropods and other organismal inclusions, found recently from the early Cretaceous of Congo and the Miocene of Ethiopia, are briefly overviewed.
\end{abstract}

Keywords: fossil resins / amber / Africa / Cretaceous / Cenozoic

\begin{abstract}
Résumé - Une révision des gisements d'ambre et de copal en Afrique et leur signification paléontologique. L'intérêt paléontologique pour les résines végétales fossiles (ambre et copal) s'est fortement accru ces dernières décennies, les études de terrain ayant permis la découverte de divers nouveaux gisements à travers le monde. Les gisements riches en ambre demeurent néanmoins particulièrement rares sur les continents autrefois gondwaniens. Nous révisons ici les occurrences connues de copal et d'ambre en Afrique, avec un bilan concernant la datation, les sources botaniques probables, le contenu fossile, ainsi que le contexte paléoenvironnemental. Les premiers ambres africains livrant des arthropodes et autres inclusions organiques fossiles, découverts récemment dans le Crétacé inférieur du Congo et le Miocène d'Ethiopie, sont brièvement présentés.
\end{abstract}

Mots clés : résines fossiles / ambre / Afrique / Crétacé / Cénozoïque

\section{Introduction}

Fossilized resins represent important sources of paleontological data for reconstructing ancient terrestrial ecosystems. A single fossiliferous deposit can provide abundant, various, and often exquisitely preserved organic inclusions (mostly arthropods, plants, protists, and fungi; more rarely microalgae, molluscs, and vertebrate remains). Fresh liquid resins solidify and progressively transform into fossil resins during burial through the chemical process of polymerization, during which their volatile compounds are lost (Anderson and Crelling, 1995; Clifford and Hatcher, 1995; Seyfullah et al., 2018). Amber is a fully polymerized, cross-linked resin that can at most softened using organic solvents. A resin that is incompletely cross-linked and not fully polymerized can dissolve in various solvents and is sometime called copal, although the use of this term is ambiguous (Anderson and

\footnotetext{
*Corresponding author: vincent.perrichot@univ-rennes1.fr
}

Crelling, 1995; Langenheim, 2003; Vávra, 2009; Lambert et al., 2012; Penney, 2016; Delclòs et al., 2020). The time needed for full polymerization greatly varies depending on the resin composition and the burial conditions, so that there is no temporal feature to characterize copal and amber. Commonly, however, copals are considered as young, semifossilized resins ranging from Recent up to the Pliocene age (5.3 Ma) (Poinar, 1992; Grimaldi, 1996; Delclòs et al., 2020). But there are older resins that are only partially polymerized and can readily dissolve, or that remain sticky and aromatic when cut or polished, and should therefore be copals. Nonetheless, these are generally classified as ambers because of their antiquity $(e$. g., Eocene Cambay "amber" from India, or Miocene "amber" from Indonesia; see Rust et al., 2010; Mazur et al., 2014; Narudeesombat et al., 2014). In the present review of all known fossil resins from Africa, "copal" and "amber" are used in this temporal sense rather than chemical sense, i.e. regardless of their level of polymerization.

The vast majority of amber deposits known today occurs in the Northern Hemisphere, particularly from the former 


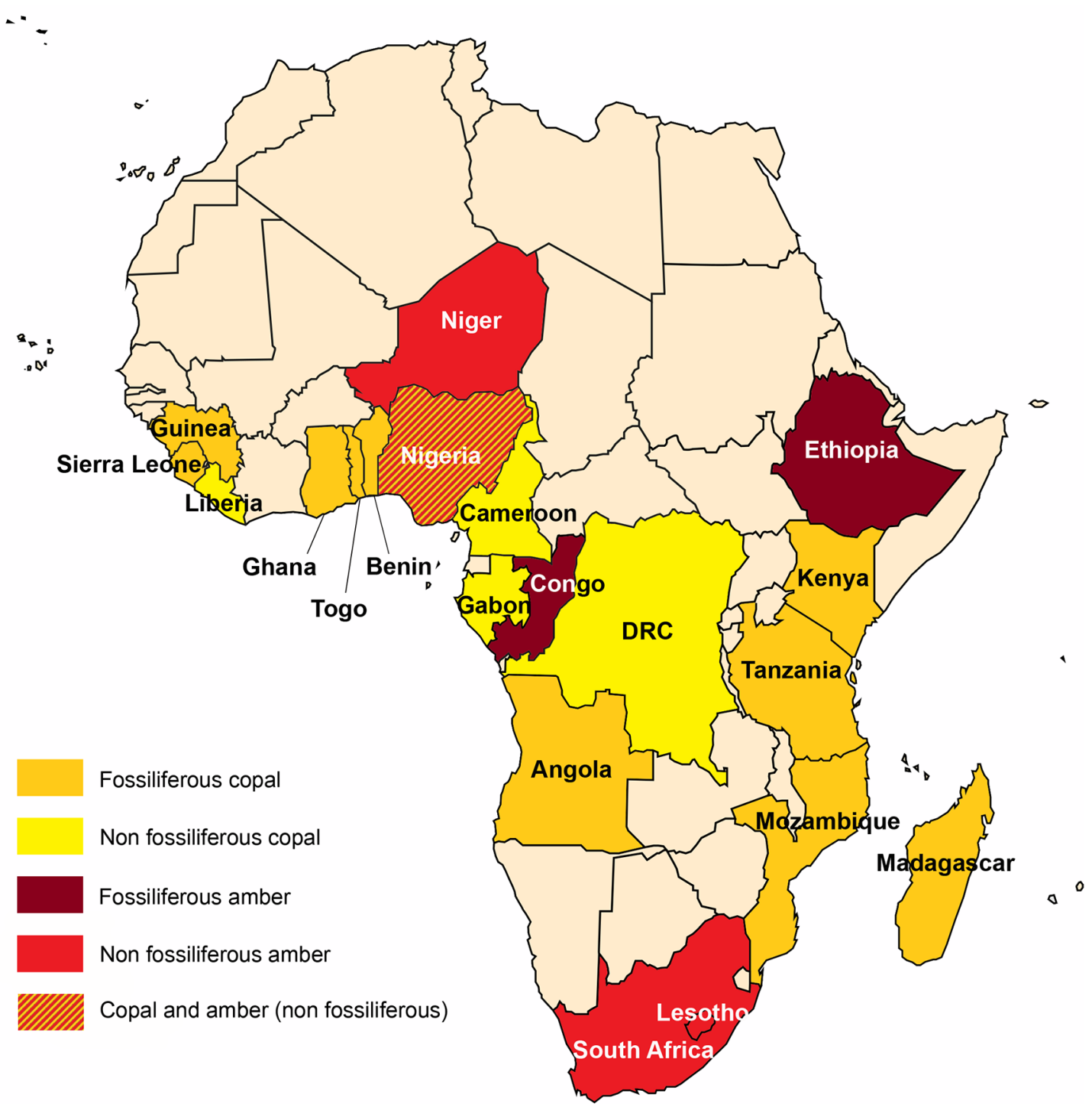

Fig. 1. Present-day map with known distribution of African deposits of fossil resins.

Laurasian continent. The paucity of Gondwanan amber deposits may results from a long lack of prospection for this geological material in the Southern Hemisphere, combined with typically limited outcrops due to the dense plant covering in intertropical zones. Amber deposits of Gondwanan origin comprise Indomalayan occurrences in India (early Eocene; Rust et al., 2010) and possibly Myanmar (early Cenomanian; at the time probably an island in the Tethys Ocean but originating from Austral Gondwana, see Rasnitsyn and ÖhmKühnle, 2018, Poinar, 2019 or Westerweel et al., 2019 for arguments); Australasian occurrences in Australia (Triassic to Neogene; Hand et al., 2010; Sonibare et al., 2014; Stilwell et al., 2020) and New Zealand (Cretaceous, Oligocene and Miocene; Schmidt et al., 2018; Mays et al., 2019; Stilwell et al., 2020); South American occurrences in Brazil (early Cretaceous; Pereira et al., 2011), Ecuador (Aptian-Albian; Cadena et al., 2018), Venezuela (Miocene, Pérez et al., 2016), and Peru (Miocene; Antoine et al., 2006); and rare African occurrences that are detailed and reviewed hereafter along with the known copal deposits.

\section{Copal}

Copal had once a major export value for its industrial use in varnishes and lacquers. A rich literature exists on African copals, their botany and their trade that developed during colonialism in the nineteenth and twentieth centuries. Abundant copal resources have been exploited mostly from two regions of the continent: Zanzibar and the German East Africa, that became a British territory after WWI, and are now corresponding to the modern Tanzania (Kirk, 1871; Schlüter and von Gnielinski, 1987; Sunseri, 2007); and the Democratic Republic of the Congo (DRC, formerly Congo Free State, then Belgian Congo) (Pynaert, 1924; De Wildeman, 1927; Vervloet, 1932; Hellinckx, 1935; Anonymous, 1942; Billing, 1944). Copal is more generally known from several countries in East Africa and West Africa (Fig. 1). All African copals derive from legume trees in the family Fabaceae, mostly Hymenaea or Guibourtia in the Caesalpinioideae group, but also Colophospermum, Copaifera, Daniellia or Tessmannia in the Detarioideae group (Howes, 1949; Langenheim, 2003; McCoy et al., 2017; Delclòs et al., 2020). 


\subsection{East African copals}

Pleistocene or even younger copal has been reported from various countries along the African East coast: Kenya, Tanzania, Mozambique, Madagascar (Fig. 1). Copal was traded into Indian Ocean networks, including India, by Swahili communities as soon as in the eighth century $\mathrm{AD}$, but a rise in the trade came with the arrival of European and American ships in Zanzibar between the sixteenth and nineteenth centuries (Hedley Barry, 1932; Howes, 1949; Sunseri, 2007; Delclòs et al., 2020). Most of the copal traded on the Zanzibar market, however, originated from the coastal forests of mainland Tanzania. This brings confusion as to whether the bioinclusions described from the so-called Zanzibar copal are actually from there or from Tanzania (Schlüter and von Gnielinski, 1987; Stroiński, 2007). Here we use Tanzanian copal in its broad sense including deposits from coastal hinterlands of Tanzania as well as the Zanzibar archipelago. The trade of East African copal, particularly that of Madagascar, has been recently reviewed by Delclòs et al. (2020).

During the eighteenth and nineteenth centuries when the trade of Tanzanian copal was most intense, interest was almost exclusively industrial or botanical (Gilg, 1898; Zimmerman, 1908). The (sub)fossil content was briefly mentioned or studied only in rare instances (Dalman, 1825; Kirk, 1871; Quedenfeldt, 1885; De Saussure, 1890). The true paleontological interest for East African copal bioinclusions started in the twentieth century, with the pioneering studies of Meunier (> 20 papers between 1900 and 1917; e.g., Meunier, 1900a, 1900b, 1905, 1917) who mostly focused on Diptera and Hymenoptera from Tanzanian and Madagascar copals. Tanzanian copal has also yielded arthropods in the orders Araneae, Scorpiones, Embiodea, Psocoptera, Blattodea, Isoptera, Lepidoptera, Auchenorrhyncha, Heteroptera, and Coleoptera (Bervoets, 1909a; Rosen, 1913; Schlüter and von Gnielinski, 1987; Stroiński and Szwedo, 2002, 2011; Stroiński 2007; Grichanov, 2008). Copals from Madagascar, and in a lesser extent from Kenya and Mozambique, have yielded various Araneae, Pseudoscorpiones, Scorpiones, Heteroptera, Neuroptera, Hymenoptera, and Coleoptera (Quedenfeldt, 1885; De Saussure, 1890; Bervoets, 1909b; Meunier, 1910a; Krinsky, 1985; Schlüter and von Gnielinski, 1987; Lourenço, 1996; Stroiński and Szwedo, 2002; Bosselaers, 2004; Wunderlich, 2004, 2008; Selden et al., 2009; Bosselaers et al., 2010; Azevedo et al., 2010; Guilbert and Heiss, 2016; Bukejs and Legalov, 2017). Finally, some insects have been reported or described without further details on their origin than "East African copal" (e.g., bees; Zeuner and Manning, 1976). In fact, most of these studies lack data on the geographical provenance and age of the copal pieces, so that the scientific value of these bioinclusions is depreciated. In Madagascar copal, for instance, many bioinclusions have been described as probably "recently extinct, subfossil", but several are species still living in African forests today, and recent studies have shown the Madagascar copal to be a Recent resin, up to a few hundred years old only (Delclòs et al., 2020).

All East African copals are assumed to derive from Hymenaea trees based on chemical characterization using gaschromatography (GC-MS), nuclear magnetic resonance $\left({ }^{13} \mathrm{C}\right.$ NMR), or Fourier transform infrared spectroscopy (FTIR)
(Lambert et al., 1995, 2012; McCoy et al., 2017; Delclòs et al., 2020); and more specifically Hymenaea verrucosa, the sole species found in East Africa and Madagascar, based on botanical considerations (Kirk, 1871; Gilg, 1898; Zimmerman, 1908; Howes, 1949; Langenheim, 1990, 2003; Delclòs et al., 2020).

\subsection{West and Central African copals}

Copals have been reported from the following countries in Western or Central Africa (Fig. 1): Angola ("Benguela copal"), Congo / DRC / Cameroon/Gabon (generally grouped under the term "Congo copal"), Liberia/Benin/Togo/Ghana/ Nigeria (sometimes grouped under "Accra copal"), Sierra Leone, and Guinea (Howes, 1949; Mantell, 1950). All are estimated Pleistocene or more recent in age, although the precise stratigraphic provenance is unknown. From these, only the Congo copal (Fig. 2A) has been exploited in great amount, particularly during Belgian colonialism in the Interwar period when it surpassed the trade of Tanzanian copal (Howes, 1949). Reports from the nineteenth century were thus essentially focused on the plant sources, collecting methods, chemical properties or commercial value of Congo copal (Rackwitz, 1907; Pynaert, 1924; De Wildeman, 1927, 1933; Vervloet, 1932; Aubréville, 1933; Louis, 1933; Mertens, 1933; Hellinckx, 1935; Anonymous, 1942; Billing, 1944; Howes, 1949; Léonard, 1950). Other West African copals have been comparatively less studied.

According to botanical observations in the above references, the legume tree Guibourtia (with species formerly assigned to the genus Copaifera) is considered to have produced most of the Congo and other West and Central African copals. But some Congo copal is also derived from Tessmannia, and copal from Angola is thought to originate from Colophospermum. Copaifera or Daniellia are also considered as important producers of copals from Benin, Ghana and Togo (Léonard, 1950; Langenheim, 2003). Resins of all these genera and Hymenaea are relatively similar in their molecular composition and are thus difficult to distinguish chemically (Lambert et al., 2002, 2009).

Only few arthropod inclusions have been reported in West African copals, most of them described in the early twentieth century: Quedenfeldt (1885) provided the earliest account from Benguela copal of Angola, with the description of two beetles in the families Elateridae and Chrysomelidae; diverse Diptera (Cecidomyiidae, Chloropidae, Muscidae, Phoridae, Psychodidae, Sciaridae) and one Neuroptera Coniopterygidae were also described from Togo and Accra copals by Meunier (1906, 1909, 1910a, 1910b, 1910c, 1910d); and a few Coleoptera and Isoptera were described from copals of Benin, Ghana, Guinea, or Sierra Leone, by Hagedorn (1905-07) and Rosen (1913), respectively. Additionally, Handlirsch (1906-08) mentioned some undescribed insects in the orders Isoptera, Blattodea, Orthoptera, Thysanoptera, Coleoptera, Hymenoptera, Lepidoptera, and Diptera, in various copal pieces from West Africa (labelled "Benin" and "Guinea"; see Schlüter and von Gnielinski, 1987). It also seems that a platypodid beetle, originally described from Baltic amber by Nunberg (1959), was in fact from a piece of West African copal (Schlüter and von Gnielinski, 1987). Finally, several Mymaridae 


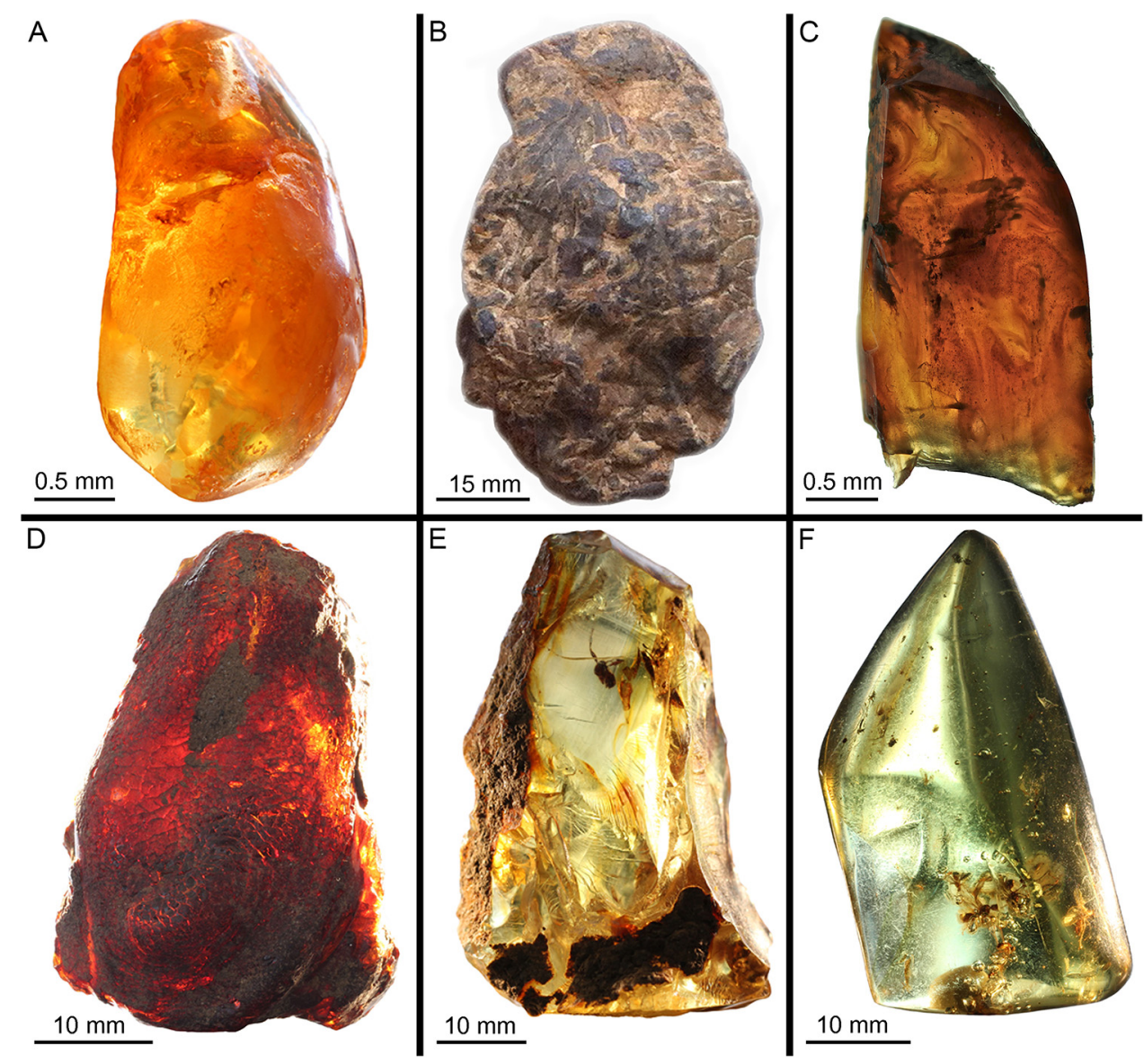

Fig. 2. Representative samples of fossil resins from Congo (A-C) and Ethiopia (D-F). A. Polished piece of orange-yellowish Congolese copal. B. Raw piece of Congolese Cretaceous amber. C. Polished piece of orange-reddish Cretaceous Congolese amber. D. Raw piece of orangeyellowish Ethiopian Miocene amber. E. Raw piece of yellow Ethiopian Miocene amber. F. Polished piece of light green Ethiopian Miocene amber.

were described from copal of unspecified localities by Meunier (1900a, 1900b), who otherwise apparently accessed East and West African copals only, so these mymarids likely originated from African copals as well.

\section{Amber}

Amber has been comparatively less frequently encountered than copal in Africa (Fig. 1). The rare occurrences until now have mostly consisted in small deposits yielding only few amber pieces apparently devoid of organic inclusions. Recently, however, the first two fossiliferous African ambers have been discovered, in Congo and Ethiopia (Schmidt et al., 2010a, 2010b; Perrichot et al., 2016, 2018). The study of these deposits and their fossil content is still in a nascent stage, so that only a preliminary review is given herein.

\subsection{Lesotho}

The oldest fossilized resin known from Africa dates back to the Upper Triassic, in the Molteno Formation, and consists of few millimeter-sized amber drops found fossilized within gymnosperm cones (Ansorge, 2007). The seed-producing gymnosperm was evidently the plant source of the resin, but its precise affinity remains unknown and a chemical characterization of such a tiny amber sample remains challenging. The tiny size and preservation within seeds has also prevented the finding of any organismal inclusions within this material.

\subsection{South Africa}

Numerous small $(\max .7 \mathrm{~mm}$ ) pieces of yellowish to red amber have been found in the Middle-Upper Valanginian (Lower Cretaceous) Kirkwood Formation (Gomez et al., 2002a, 2002b). The amber-bearing rock also yielded abundant remains of Brachyphyllum, a conifer genus of ill-defined position within the Araucariaceae or Cheirolepidiaceae, and possibly the resin-producer. This amber is devoid of inclusion. Paleobotanical and taphonomical studies suggest that the resin was produced under a warm to hot, semi-arid climate, and was washed from its primary environment into a fluvial deposit during a flooding event (Gomez et al., 2002a).

\subsection{Congo}

The only fossiliferous Cretaceous amber from the continent has been discovered in 2011 near Doumanga, in the Mayombe belt, $70 \mathrm{~km}$ NE of Pointe-Noire. Amber and 
V. Bouju and V. Perrichot: BSGF 2020, 191, 17

Table 1. List of most significant bioinclusions in newly excavated amber from Congo and Ethiopia.

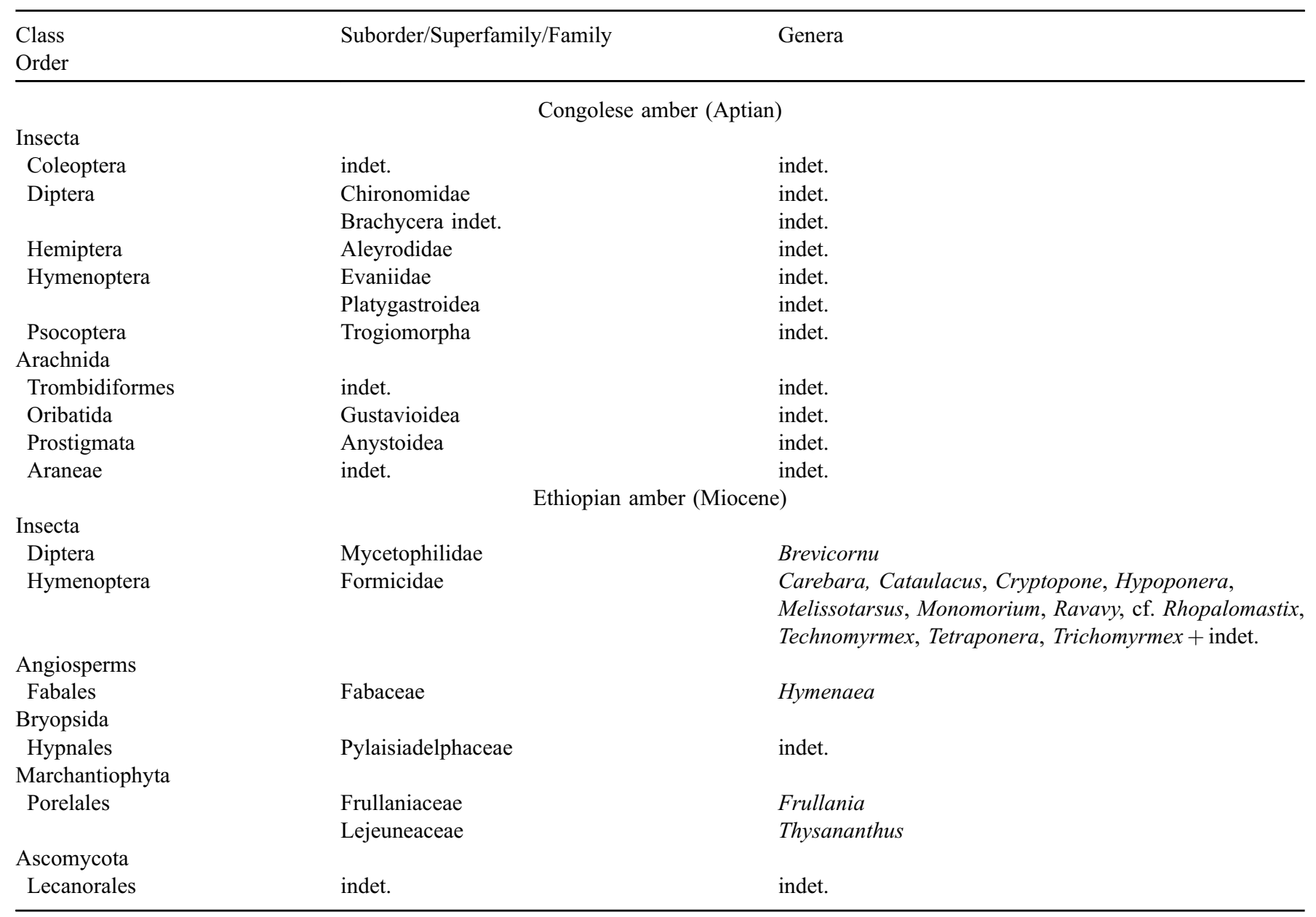

plant debris, including lignite and fusinite, have accumulated in lags within the Vembo Shales, a member of the Chéla Formation that was dated as middle Aptian based on the palynomorphs and ostracods from the amber-bearing shales (Delhaye-Prat et al., 2016; Perrichot et al., 2016). An excavation by one of us (VP) in 2013 yielded about 5000 amber pieces, all dark, red to orange in color (Figs. 2B and 2C), commonly pebble-shaped, and up to $12 \mathrm{~cm}$ in diameter. Analysis of small, translucent pieces in light microscopy revealed the first arthropods, while synchrotron imaging has been used to radiograph a first portion of dark, larger pieces. The studied sample appears moderately fossiliferous, with a dozen families identified in 9 arthropod orders (Tab. 1; Figs. 3A and 3B). Plant debris (stellate hairs, wood fibers, spores) or fungal/bacterial remains also occur in many pieces.

The molecular composition of Congolese amber indicates a Group A in ${ }^{13} \mathrm{C}-\mathrm{NMR}$ (sensu Lambert and Poinar, 2002) and Class Ib in THM-GC-MS (sensu Anderson, 1994), indicative of resins from the conifer families Araucariaceae, Cupressaceae, Podocarpaceae, and Cheirolepidiaceae. The wood remains associated in the amber-bearing rock belong to Brachyoxylon and Agathoxylon, and the palynomorphs comprise Araucariacites and dominant Classopollis, suggesting an Araucariaceae or Cheirolepidiaceae as the plant source. Amber and plant debris were washed into a saline, lacustrine environment in a small, inland, rift basin connected to the ocean, and accumulated in flood related gravity driven deposits, as indicated by sedimentological and taphonomical studies. In addition with paleobotanical data, it also suggests a hot paleoclimate with contrasted, humid and dry seasons (Delhaye-Prat et al., 2016).

\subsection{Niger}

Small, isolated pieces of reddish amber have been collected in 2016 at Takalmaoua, Department of Dakoro, in Maradi Region. The amber was found in a well, at a depth of about $50 \mathrm{~m}$, within rocks of Cenomanian/Senonian age (A. Moumouni, personal communication). A chemical characterization of this amber by thermochemolysis gaschromatography-mass spectrometry (THM-GC-MS) has indicated a Class Ib amber (sensu Anderson, 1994), thus originating from a conifer (Perrichot, unpublished data). The few available pieces did not provide any inclusion.

\subsection{Nigeria}

A Lutetian or Lower Bartonian (Eocene) amber, named Amekit, has been found in the Ameki Formation near Umuahia, in southeastern Nigeria (Wilson, 1925; Arua, 1979; 

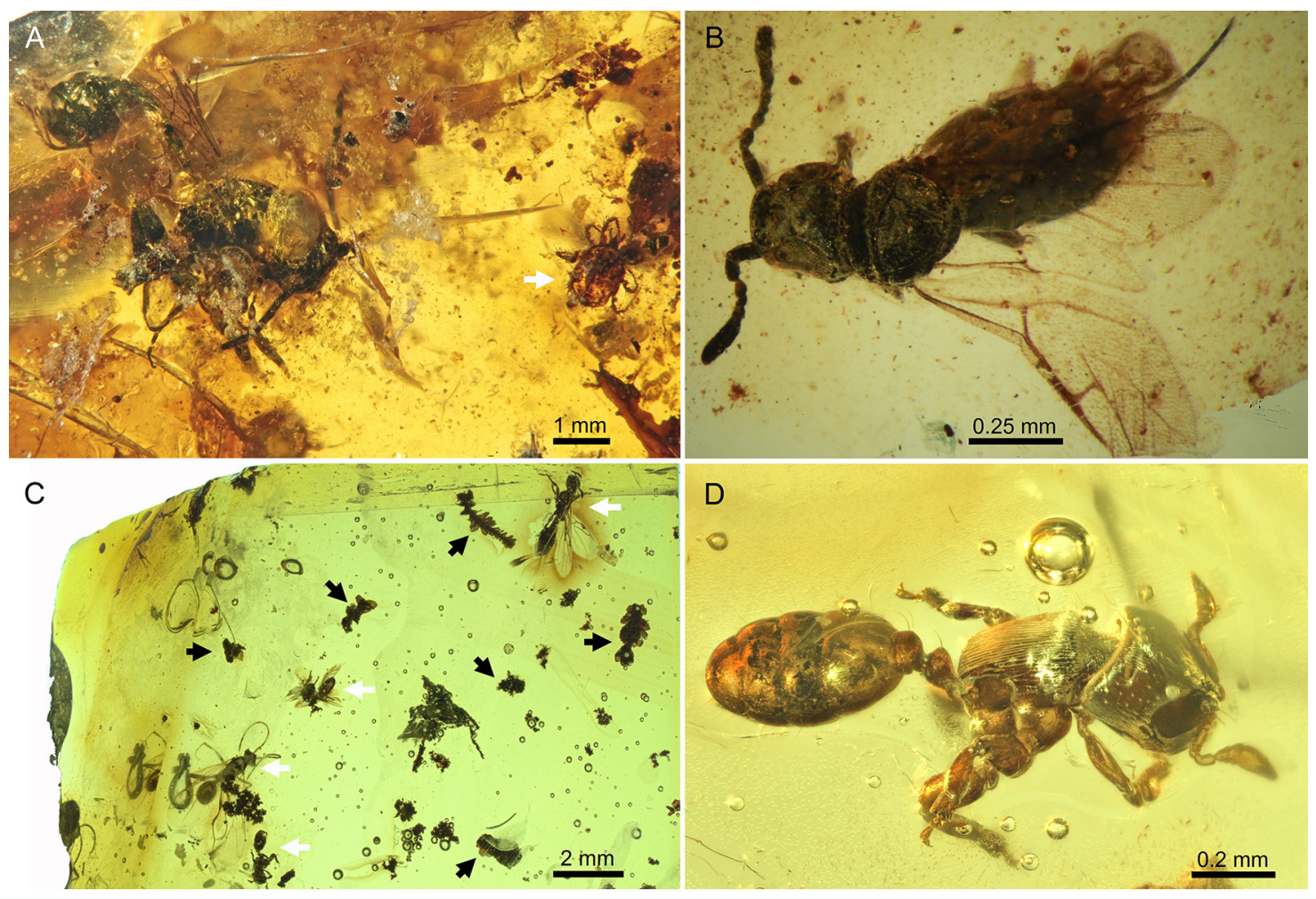

Fig. 3. Representative inclusions of arthropods and plants in African amber (coll. Univ. Rennes). A. Female evaniid wasp (Hymenoptera: Evaniidae) and trombidiform mite (Acari; white arrow) in Congolese Cretaceous amber. B. Parasitic wasp (Hymenoptera: Platygastroidea) in Congolese Cretaceous amber. C. Various myrmicine ants (Hymenoptera: Formicidae; indicated by white arrows) and bryophytes (Marchantiophyta; indicated by black arrows) in Ethiopian Miocene amber. D. A worker ant of the genus Melissotarsus (Hymenoptera: Formicidae) in Ethiopian Miocene amber.

Savkevitch and Arua, 1990). Amber chunks occur within three successive sedimentary facies of this formation, and are generally associated with lignite and various marine organisms, suggesting they were washed into a marginal lagoon environment from a nearby mangrove-swamp area (Arua, 1979, 1986). An angiosperm source has been suggested for Amekit based on the absence of gymnosperms among the fossil plants from the amber-bearing strata (Rao and Kumaran, 1988). But the molecular characterization of the amber by infrared spectroscopy and gas chromatography-mass spectrometry (Py- and THMGC-MS) indicates a Class Ib amber typical of conifers, possibly the family Cupressaceae (Sonibare et al., 2012). No organismal inclusions has ever been mentioned from this amber despite large pieces of yellow or dark red, translucent amber (Arua, 1979). However, there has been virtually no material available for screening by paleoentomologists since the formal description of this amber four decades ago.

It is possible that an older amber also exists in southern Nigeria, as mentioned by Le Gall et al. (2010). Indeed, some pieces were found associated with mosasaur teeth and ammonites in the Upper Cretaceous (Maastrichtian) strata that outcrop between Enugu and Port Harcourt, thus in the surroundings of the Ameki Formation $(\mathrm{Ph}$. Courville, personal communication). Whether this corresponds to a true Cretaceous, primary deposition, or a redeposition after the erosion of above layers would require further investigation. But fieldwork in Nigeria is currently hampered by the geopolitical situation.

\subsection{Ethiopia}

The richest sources of amber in Africa are outcrops located in the gorges of the Wenchit, Jemma, and Mugher rivers incising the northwestern Ethiopian plateau in the North Shewa Zone of the Amhara Region. At least 20 kilograms of amber are extracted annually by villagers, apparently with all excavations in a same siltstone that was erroneously attributed to a Cretaceous unit, the Debre Libanos Sandstone (Schmidt et al., 2010a; Kiefert, 2015). The Cretaceous age of the rock was suggested by local geologists based on field observations and correspondence with the geological map of Belay et al. (2009); it was also estimated based on the analysis of the chemical features of the amber and the sporomorphs of the associated sediment (Schmidt et al., 2010a). However, two of the sporomorphs that had been identified as Cretaceous taxa were mistaken, and other sporomorphs that had been left undetermined have eventually been identified as long ranging Cenozoic taxa (Perrichot et al., 2016). Recent investigation of additional amber material has provided arthropod and plant inclusions that belong almost exclusively to extant genera (Tab. 1), therefore modern lineages which definitely rule out a Cretaceous age. Additionally, the rocks associated with this new material have yielded palynomorph assemblages that are indicative of an Early Miocene age (Perrichot et al., 2018). According to geological studies, the only sedimentary rocks known in this area are either Upper Cretaceous, referred to as Debre Libanos Sandstone or Upper Sandstone; or Upper 
V. Bouju and V. Perrichot: BSGF 2020, 191, 17

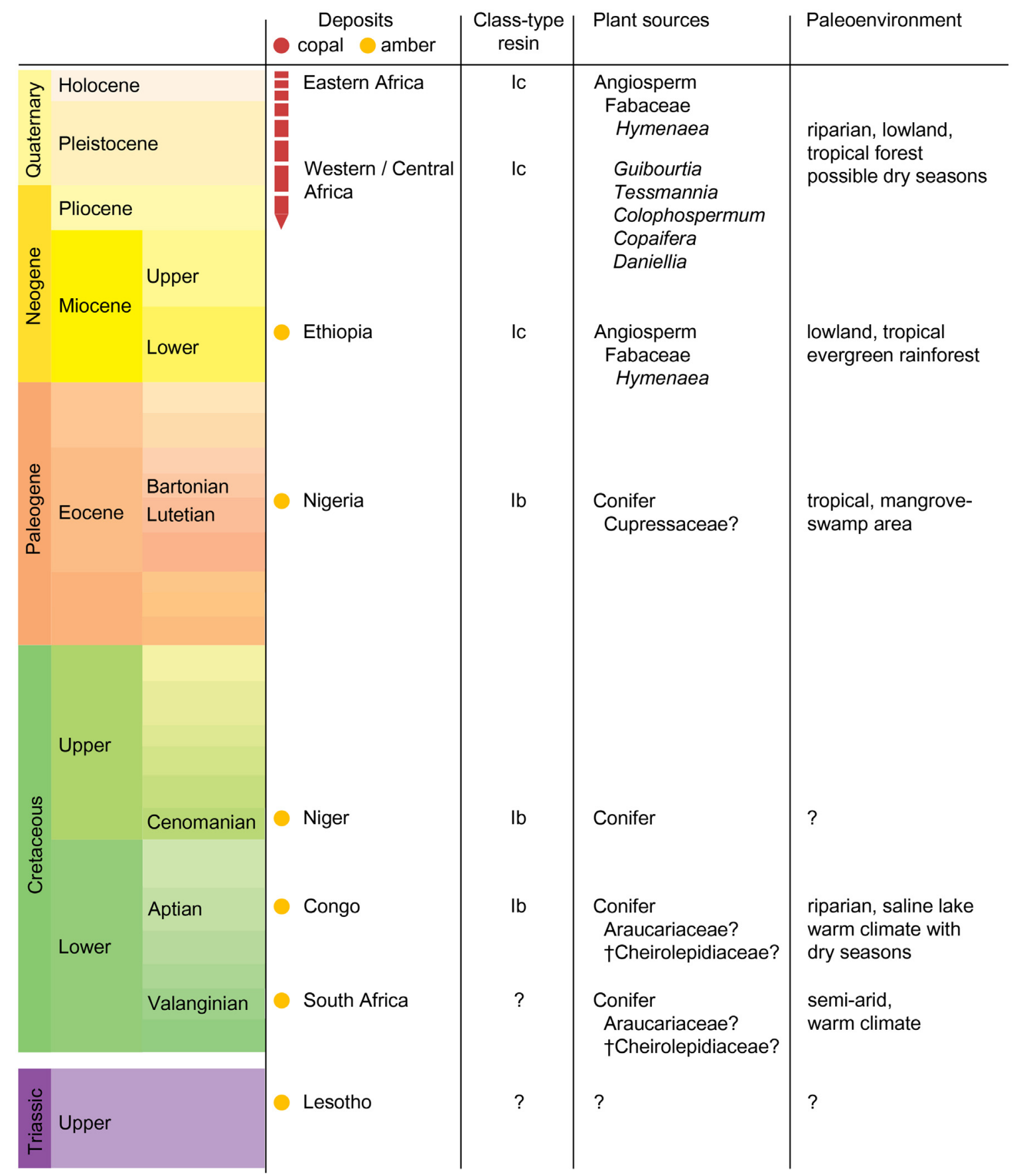

Fig. 4. Synoptic diagram of the main characteristics of African fossil resins and their corresponding paleoenvironments.

Miocene, referred to as “Tertiary sediments" (Belay et al., 2009). Data are yet insufficient to explain this incongruence with the Early Miocene age suggested by our paleontological results.

Ethiopian amber is hard, translucent, with colors ranging from orange to yellow greenish, light green, or dark green (Figs. 2D-2F), and pieces are commonly $5 \mathrm{~cm}$ or more in size. Analysis of nine amber samples in THM-GC-MS has consistently recovered a Class Ic amber, regardless of the color, and comparison with the spectra obtained from Dominican and Mexican ambers suggests the angiosperm family Fabaceae as the plant-source (unpublished pers. data).
The finding of fossil leaves and stamens of Hymenaea in several amber pieces similarly suggests this legume tree as the resin producer (J. Szwedo, personal communication).

The first study of Ethiopian amber had already recovered a diversity of arthropod and fungal inclusions (Schmidt et al., 2010a, 2010b). Newly investigated material confirms the richness of Ethiopian amber inclusions and undoubtedly shows taxonomic affinities with Cenozoic biota (Tab. 1; Figs. 3C and 3D). Remarkably, this amber yields a fairly high proportion of plant inclusions, among which frequent remains of liverworts (Marchantiophyta) and angiosperms (Fabales), more rarely 
leafy mosses (Hypnales) and lichens (Lecanorales). Most plant and insect taxa found as inclusions are reported for the first time from the African fossil record (e.g., Frullaniaceae, Lejeuneaceae, Pylaisiadelphaceae, Formicidae: Dorylinae, Pseudomyrmecinae, Mycetophylidae). And many taxa are the first fossil occurrence of extant genera, thus bridging a gap in the evolutionary history of the corresponding lineages. A particular focus has been made on ants, revealing at least 13 genera, 10 of which are still extant. Several of these contemporary genera have relatively recent crown-group origins, for instance with the following age estimates obtained from molecular phylogenetic analyses ("Mean" values, in Ma): Hypoponera (30-37) for Ponerinae (Schmidt, 2013); Ravavy (27) and Technomyrmex (23-33) for Dolichoderinae (Ward et al., 2010); Cataulacus (18.3-20.4) and Trichomyrmex (20-22.7) for Myrmicinae (Blaimer et al., 2018). These occurrences support a Miocene maximal age dating for Ethiopian amber.

Finally, the palynomorph assemblages are suggestive of a lowland tropical rainforest, without any marine input. The presence of abundant liverworts assignable to Lejeuneaceae similarly indicates a humid tropical forest. Ethiopian amber was thus derived from Hymenaea trees likely growing in evergreen rainforests, rather than in dry environments like some recent Hymenaea species (Langenheim et al., 1973).

\section{Conclusion}

Several evolutionary trends can be seen from the few African deposits of fossil resin (Fig. 4). Ancient, Cretaceous to Eocene resins were all derived from conifers (class Ib type resins) while younger, Miocene to Recent resins derive from angiosperms in the Fabaceae family (class Ic type resins). Also, Araucariaceae or Cheirolepidiaceae were apparently the dominant amber-producers during the Early and mid-Cretaceous (South-Africa, Valanginian; Congo, Aptian), possibly replaced by Cupressaceae in the Eocene (Nigeria). This is similar to the global pattern, observed from amber deposits worldwide, of a shift to dominance of resin-production by Cupressaceae or Pinaceae in the Late Cretaceous, and by (sub) tropical angiosperms in the mid-Cenozoic, with the exception of the kauri copal produced by Agathis (Langenheim, 2003; Nohra et al., 2015; Seyfullah et al., 2018).

This change in the resin-producing trees was accompanied by a change in climate and environment. For the Cretaceous, sedimentary and fossil data in South Africa and Congo indicate a warm, subtropical climate with at least temporary arid conditions. From the Eocene onward, ambers from Nigeria and Ethiopia, and copals from eastern and western-central Africa have derived from lowland, tropical evergreen rainforests with (Nigeria) or without (Ethiopia) marine influence. Further study of fossil inclusions of fungi, plants, and arthropods from Congolese and Ethiopian ambers will thus likely further substantiate such contrasted habitats.

Acknowledgements. We are grateful to all colleagues and persons who contributed to the discovery or study of Congolese amber: V. Delhaye-Prat and colleagues from Total Exploration-Production Congo (Pau, France), Anaïs Boura (UPMC, France), Johanne Esnault and Laurent Jeanneau (Univ. Rennes, France), Carmen Soriano (Argonne Photon
Source, Chicago). We are also indebted to all persons who contributed the access or the study of Ethiopian amber: Brendon Boudinot (Univ. California, Davis), Cédric Chény (Univ. Rennes, France), Jim Cole (Tie-Point Geoscience Ltd., UK), Yale Goldman (Collinsville, Connecticut), Alexander R. Schmidt (Univ. Göttingen, Germany), Matthias Svojtka (Univ. Vienna, Austria), Jacek Szwedo and Blazej Bojarski (Univ. Gdańsk, Poland), Bo Wang (NIGPAS, China), Benyam Teferi (Addis Ababa, Ethiopia), and Amde Zewdalem (Jacksonville, Florida). We warmly thank Ali Moumouni (Univ. Maradi, Niger) and Philippe Courville (Univ. Rennes, France) for information or samples of amber from Niger and Nigeria, and SP Demonvielle (Brazzaville) for samples of Congolese copal. And we thank the guest editors Jean-Paul Saint Martin and Simona Saint Martin for inviting us to contribute this thematic volume, and Alexander Schmidt and an anonymous reviewer for their helpful comments. This work was partly supported by the Tellus-INTERRVIE program of CNRS INSU (project AMBRAFRICA to V.P.).

\section{References}

Anderson KB. 1994. The nature and fate of natural resins in the geosphere-IV. Middle and Upper Cretaceous amber from the Taimyr Peninsula, Siberia-Evidence for a new form of polylabdanoid of resinite and revision of the classification of Class I resinites. Organic Geochemistry 21: 209-212.

Anderson KB, Crelling JC. 1995. Introduction. In: Anderson KB, Crelling JC, eds. Amber, resinite, and fossil resins. American Chemical Society Symposium Series 617: xi-xvii.

Anonymous. 1942. Le copal. Bruxelles: Publications de l'Office Colonial, pp. 1-7.

Ansorge J. 2007. Upper Triassic insects and amber from Lesotho. In: 4th International Conference on Fossil Insects, Arthropods and Amber, Pretoria, South Africa. Abstract book, pp. 52-54.

Antoine PO, De Franceschi D, Flynn JJ, Nel A, Baby P, Benammi M, et al. 2006. Amber from western Amazonia reveals Neotropical diversity during the middle Miocene. Proceedings of the National Academy of Sciences of the USA 103: 13595-13600. https://doi. org/10.1073pnas.0605801103.

Arua I. 1979. Eocene amber from the Umuchia-Bende area. The Nigerian Field 44: 119-126.

Arua I. 1986. Paleoenvironment of Eocene deposits in the Afikpo syncline, southern Nigeria. Journal of African Earth Sciences 5: 279-284.

Aubréville AM. 1933. Les copaliers de l'Afrique occidentale française. Bulletin de l'Agence Générale des Colonies 292: 981-986.

Azevedo CO, Madl M, Olmi M. 2010. A catalogue of the Bethylidae, Chrysididae, Dryinidae, Embolemidae, Sclerogibbidae and Scolebythidae (Hymenoptera: Chrysidoidea) of the Malagasy subregion. Linzer Biologische Beiträge 42(2): 845-918.

Belay T, Tesfay I, Ayalew A, Yohannes G, Zewdie T, Bekele H, et al. 2009. Geology of the Were-Ilu area. Geological Survey of Ethiopia, Memoir 25: 56 pp. + map.

Bervoets R. 1909a. Un Coréide nouveau du copal récent de Zanzibar [Hem. Coreidae]. Bulletin de la Société Entomologique de France 14(19): 331-332.

Bervoets R. 1909b. Un Aradide nouveau du copal récent de Madagascar [Hem. Aradidae]. Bulletin de la Société Entomologique de France 14(16): 280-281. 
Billing HJ. 1944. Congo copal. The Oil and Colour Trades Journal 3: 666-668.

Blaimer BB, Ward PS, Schultz TR, Fisher BL, Brady SG. 2018. Paleotropical diversification dominates the evolution of the hyperdiverse ant tribe Crematogastrini (Hymenoptera: Formicidae). Insect Systematics and Diversity 2(5): 3. https://doi.org/ 10.1093/isd/ixy013.

Bosselaers J. 2004. A new Garcorops species from Madagascar copal (Araneae: Selenopidae). Zootaxa 445: 1-7.

Bosselaers J, Dierick M, Cnudde V, Masschaele B, van Hoorebeke L, Jacobs P. 2010. High-resolution X-ray computed tomography of an extant new Donuea (Araneae: Liocranidae) species in Madagascan copal. Zootaxa 2427: 25-35.

Bukejs A, Legalov AA. 2017. New species of sub-fossil weevils (Coleoptera, Curculionidae) in Madagascar copal. Paleontological Journal 51: 196-202. https://doi.org/10.1134/S003103011702006X.

Cadena EA, Mejia-Molina A, Brito CM, Peñafiel S, Sanmartin KJ, Sarmiento LB. 2018. New Mesozoic and Cenozoic fossils from Ecuador: Invertebrates, vertebrates, plants, and microfossils. Journal of South American Earth Sciences 83: 27-36. https:// doi.org/10.1016/j.jsames.2018.02.004.

Clifford DJ, Hatcher PG. 1995. Structural transformations of polylabdanoid resinites during maturation. Organic Geochemistry 23: 407-418.

Dalman J. 1825. Om Insekter inneslutna i copal, jeinte beskrifning pa nagra, deribland förekommande nya slägten och arter. Kungliga Svenska Vetenskapsakademiens Handlingar 46: 375-410.

Delclòs X, Peñalver E, Ranaivosoa V, Solórzano-Kraemer MM. 2020. Unravelling the mystery of "Madagascar copal": Age, origin and preservation of a Recent resin. PLoS ONE 15: e0232623. https:// doi.org/10.1371/journal.pone.0232623.

Delhaye-Prat V, Dupont G, Buratti N, Moron JM, Esnault J, Perrichot $\mathrm{V}$, et al. 2016. The Vembo Shales (Republic of the Congo): New insights on the transition from lacustrine to marine settings for the South Atlantic. In: 35th International Geological Congress. AGI GeoRef Database, Paper n 2850 (https://www.americangeoscien ces.org/igc/15032).

De Saussure H. Histoire naturelle des Hyménoptères. In: Grandidier A, ed. Histoire Physique, Naturelle et Politique de Madagascar, vol. 20. Paris : Imprimerie Nationale, 1890 [1892], xxi + 590 p.

De Wildeman E. 1927. Matériaux pour la flore forestière du Congo Belge. XIII. Sur un producteur de copal. Annales de la Société Scientifique de Bruxelles 47: 118-124.

De Wildeman E. 1933. Quelques considérations sur les résines dénomées «Copals ». Bulletin des séances - Institut Royal Colonial Belge 4(2): 478-497.

Gilg E. 1898. Ueber Gummi, Copale und andere Harze Afrikas. Chemische Revue 5 (9): 172-178. https://doi.org/10.1002/ lipi.18980050903.

Gomez B, Bamford M, Martínez-Delclòs X. 2002a. Lower Cretaceous plant cuticles and amber (Kirkwood Formation, South Africa). Comptes Rendus Palevol 1: 83-87.

Gomez B, Martínez-Delclòs X, Bamford M, Philippe M. 2002b. Taphonomy and palaeoecology of plant remains from the oldest African Early Cretaceous amber locality. Lethaia 35: 300-308.

Grichanov IY. 2008. Systematic notes on Sciapodinae from Baltic amber and on Dolichopodidae from Tanzanian copal (Diptera). Caucasian Entomological Bulletin 4: 137-139.

Grimaldi DA. 1996. Amber: window to the Past. New York: Harry N. Abrams, Inc.

Guilbert E, Heiss E. 2016. First fossil records of Tingidae from Madagascan copal with description of two new species (Hemiptera, Heteroptera). Linzer Biologische Beiträge 48: 1081-1090.
Hagedorn M. 1905-07. Kopalborkenkäfer. Verhandlungen des Vereins für Naturwissenschaftliche Unterhaltung zu Hamburg 13: 109-112.

Hand S, Archer M, Bickel D, Creaser P, Dettmann M, Godthelp H, et al. Australian Cape York amber. In: Penney D, ed. Biodiversity of fossils in amber from the major world deposits. Manchester, UK: Siri Scientific Press, 2010, pp.69-79.

Handlirsch A. 1906-08. Die fossilen Insekten und die Phylogenie der rezenten Formen. Ein Handbuch für Paläontologen und Zoologen. Leipzig: Vertrag Wilhelm von Engelmann.

Hedley Barry T. 1932. Natural varnish resins. London: Ernest Benn Ltd.

Hellinckx L. 1935. Etudes sur le Copal-Congo. Mémoires de l'Institut Royal Colonial Belge 8: 1-63.

Howes FN. 1949. Vegetable Gums and Resins. Waltham, Massachusetts: Chronica Botanica.

Kiefert L. 2015. Natural green amber from Ethiopia. In: 34th International Gemmological Conference, Vilnius, Lithuania. Abstract book, pp. 22-25.

Kirk J. 1871. On the copal of Zanzibar. Journal of the Linnean Society. Botany 11: 1-4. https://doi.org/10.1111/j.1095-8339.1869. tb00047.x.

Krinsky WL. 1985. A Propalticus species in Kenyan amber (Coleoptera: Propalticidae). The Coleopterists Bulletin 39: 101-102.

Lambert JB, Johnson SC, Poinar GO Jr. 1995. Resin from Africa and South America: Criteria for distinguishing between fossilized and recent resin based on NMR spectroscopy. In: Anderson KB, Crelling JC, eds. Amber, resinite, and fossil resins. American Chemical Society Symposium Series 617: 193-202.

Lambert JB, Heckenbach EA, Hurtley AE, Wu Y, Santiago-Blay JA. 2009. Nuclear magnetic resonance spectroscopic characterization of legume exudates. Journal of Natural Products 72: 1028-1035.

Lambert JB, Poinar GO Jr. 2002. Amber: The organic gemstone. Accounts of Chemical Research 35: 628-636.

Lambert JB, Tsai CY, Shah MC, Hurtley AE, Santiago-Blay JA. 2012. Distinguishing amber and copal classes by proton magnetic resonance spectroscopy. Archaeometry 54: 332-348. https://doi. org/10.1111/j.1475-4754.2011.00625.x.

Lambert JB, Wu Y, Santiago-Blay JA. 2002. Modern and ancient resins from Africa and the Americas. In: Jakes KA, ed. Archeological chemistry. Materials, methods, and meaning. American Chemical Society Symposium Series 831: 64-83.

Langenheim JH. 1990. Plant resins. American Sciences 78: 16-24.

Langenheim JH. 2003. Plant resins: chemistry, evolution, ecology, and ethnobotany. Portland, Oregon: Timber Press.

Langenheim JH, Lee YT, Martin SS. 1973. An evolutionary and ecological perspective of Amazonian Hylaea species of Hymeneae (Leguminosae: Caesalpinioideae). Acta Amazonica 3: 5-38.

Le Gall P, Silvain JF, Nel A, Lachaise D. 2010. Les insectes actuels témoins des passés de l'Afrique : essai sur l'origine et la singularité de l'entomofaune de la région afrotropicale. Annales de la Société Entomologique de France 46: 297-343.

Léonard J. 1950. Etude botanique des copaliers du Congo Belge. Publications de l'Institut National pour l'Etude Agronomique du Congo Belge, série scientifique 45: 1-158.

Louis MJ. 1933. L'origine botanique du copal. Bulletin Agricole du Congo Belge 19: 838-839.

Lourenço WR. 1996. Premier cas connu d'un sub-fossile de scorpion dans le copal de Madagascar. Comptes Rendus de l'Académie des Sciences, Paris, série IIa 323: 889-891.

Mantell CL. 1950. The natural hard resins: their botany, sources and utilization. Economic Botany 4(3): 203-242. 
Mays C, Coward AJ, O'Dell LA, Tappert R. 2019. The botanical provenance and taphonomy of Late Cretaceous Chatham amber, Chatham Islands, New Zealand. Review of Palaeobotany and Palynology 260: 16-26. https://doi.org/10.1016/j. revpalbo.2018.08.004.

Mazur N, Nagel M, Leppin U, Bierbaum G, Rust J. 2014. The extraction of fossil arthropods from Lower Eocene Cambay amber. Acta Palaeontologica Polonica 59: 455-459. https://doi.org/ 10.4202/app.2012.0018.

McCoy VE, Boom A, Solórzano Kraemer MM, Gabbott SE. 2017. The chemistry of American and African amber, copal, and resin from the genus Hymenaea. Organic Geochemistry 113: 43-54. https://doi.org/10.1016/j.orggeochem.2017.08.005.

Mertens E. 1933. Recherches sur le copal du Congo. Bulletin des séances-Institut Royal Colonial Belge 4: 268-291.

Meunier F. 1900a. Sur les Mymaridae de l'ambre et du copal (Hymén.). Bulletin de la Société Entomologique de France 1900: 364-367.

Meunier F. 1900b. Sur quelques Mymaridae du copal fossile. Bulletin de la Société Entomologique de France 1900: 192-195.

Meunier F. 1905. Sur quelques diptères et un hyménoptère du copal récent de Madagascar. Miscellanea Entomologica 13: 90-94.

Meunier F. 1906. Sur quelques insectes (Diptères, Hyménoptères, Névroptères, Orthoptères) du copal fossile, sub-fossile et récent de Zanzibar et du copal récent d'Accra, du Togo et de Madagascar. Annales de la Société Scientifique de Bruxelles 30: 211-213.

Meunier F. 1909. Quelques considérations sur la faune d'insectes du copal fossile de Zanzibar, du copal récent d'Accra, de Zanzibar et de Madagascar. Annales de la Société Scientifique de Bruxelles 33: 141-142.

Meunier F. 1910a. Contribution à la faune des diptères du copal récent de Zanzibar, de Madagascar et d'Accra. Annales de la Société Scientifique de Bruxelles 34: 5-13.

Meunier F. 1910b. Contribution à la faune des Phoridae du copal subfossile de Zanzibar, du copal récent de Zanzibar, Accra et de Madagascar. Annales de la Société Scientifique de Bruxelles 34: 144-145.

Meunier F. 1910c. Contribution à la faune des Phoridae du copal subfossile de Zanzibar, récent de Zanzibar, de Madagascar et d'Accra. Le Naturaliste 32: 18-20.

Meunier F. 1910d. Un Coniopterygidae du copal récent du Togo (Afrique). Bulletin de la Société Entomologique de France 1910: 119-120.

Meunier F. 1917. Note complémentaire concernant Styringomyia venusta Loew du copal récent de Zanzibar. Tijdschrift voor Entomologie 60: 370-375.

Narudeesombat N, Ounorn P, Bupparenoo P, Christopherse A, Pisutha-Arnond V, Sutthirat C. 2014. Update on the characteristics of amber from Indonesia. Proceedings of the 4th International Gem and Jewelry Conference (GIT 2014), Thailand 271-276.

Nohra YA, Perrichot V, Jeanneau L, Le Pollès L, Azar D. 2015. Chemical characterization and botanical origin of French ambers. Journal of Natural Products 78: 1284-1293. https://doi.org/ 10.1021/acs.jnatprod.5b00093.

Nunberg M. 1959. Eine fossile Kernkäfer-Art aus der Gattung Periommatus Chap. (Platypodidae). Annales Zoologici 18: 127-138.

Penney DA. 2016. Sub/fossil resin research in the 21st Century: Trends and perspectives. Paläontologische Zeitschrift 90: 425-447.

Pereira R, San Gil RAS, Carvalho IS, Fernandes ACS, Azevedo DA. 2011. Solid state 13C NMR analysis of Brazilian Cretaceous ambers. Journal of Brazilian Chemical Society 22: 92-97.
Pérez LM, Panera JPP, Aguilera OA, Ronchi DI, Sánchez R, Manceñido MO, et al. 2016. Palaeontology, sedimentology, and biostratigraphy of a fossiliferous outcrop of the Early Miocene Querales Formation, Falcón Basin, Venezuela. Swiss Journal of Palaeontology 135: 187-203.

Perrichot V, Boudinot BE, Cole J, Delhaye-Prat V, Esnault J, Goldman Y, et al. African fossiliferous amber: A review. In: Penney D, Ross AJ, Eds. Abstract book of the 7th international conference on fossil insects, arthropods and amber. Manchester, UK: Siri Scientific Press, 2016, p. 41.

Perrichot V, Boudinot B, Chény C, Cole J, Jeanneau L, Schmidt AR, 2018. The age and paleobiota of Ethiopian amber revisited. In: 5 th International Paleontological Congress, Paris, France. Abstract book: 23.

Poinar G Jr. 1992. Life in amber. Stanford: Stanford University Press.

Poinar G Jr. 2019. Burmese amber: Evidence of Gondwanan origin and Cretaceous dispersion. Historical Biology 31: 1304-1309. https://doi.org/10.1080/08912963.2018.1446531.

Pynaert L. 1924. Le copal et son exploitation au Congo belge. Bulletin Agricole du Congo Belge 15(2): 334-359.

Quedenfeldt G. 1885. Copal-Insekten aus Africa. Berliner Entomologische Zeitschrift 29: 363-365.

Rao VR, Kumaran KPN. 1988. A short survey of palaeobotanic studies (Cretaceous and Tertiary) in Nigeria. Review of Palaeobotany and Palynology 54: 151-158.

Rackwitz H. 1907. Über die westafrikanische Copale, speziell den Angola-Copal (rot) und Kamerun-Copal. Archiv der Pharmazie 245: 415-426.

Rasnitsyn AP, Öhm-Kühnle C. 2018. Three new female Aptenoperissus from mid-Cretaceous Burmese amber (Hymenoptera, Stephanoidea, Aptenoperissidae): unexpected diversity of paradoxical wasps suggests insular features of source biome. Cretaceous Research 91: 168-175. https://doi.org/10.1016/j. cretres.2018.06.004.

Rosen K. von. 1913. Die fossilen Termiten: eine kurze Zusammenfassung der bis jetzt bekannten Funde. Transactions of the 2nd International Congress of Entomology, pp. 318-335.

Rust J, Singh H, Rana RS, McCann T, Singh L, Anderson K, et al. 2010. Biogeographic and evolutionary implications of a diverse paleobiota in amber from the early Eocene of India. Proceedings of the National Academy of Sciences of the USA 107: 18360-18365. https://doi.org/10.1073/pnas.1007407107.

Savkevitch SS, Arua I. 1990. Amekit, a new fossil resin from Nigeria. Prace Muzeum Ziemi 41: 156.

Schlüter T, von Gnielinski F. 1987. The East African copal-Its geologic, stratigraphic, palaeontologic significance and comparison with other fossil resins of similar age. National Museums of Tanzania Occasional Paper 8: 1-32.

Schmidt C. 2013. Molecular phylogenetics of ponerine ants (Hymenoptera: Formicidae: Ponerinae). Zootaxa 3647: 201-250.

Schmidt AR, Perrichot V, Svojtka M, Anderson KB, Belete KH, Bussert R, et al.2010a. Cretaceous African life captured in amber. Proceedings of the National Academy of Sciences of the USA 107: 7329-7334. https://doi.org/10.1073/pnas.1000948107.

Schmidt AR, Dörfelt H, Struwe S, Perrichot V. 2010b. Evidence for fungivory in Cretaceous amber forests from Gondwana and Laurasia. Palaeontographica B 283: 157-173.

Schmidt AR, Kaulfuss U, Bannister JM, Baranov V, Beimforde C, Bleile N, et al. 2018. Amber inclusions from New Zealand. Gondwana Research 56: 135-146. https://doi.org/10.1016/j. gr.2017.12.003.

Selden PA, Anderson HM, Anderson JM. 2009. A review of the fossil record of spiders (Araneae) with special reference to Africa, and 
description of a new specimen from the Triassic Molteno Formation of South Africa. African Invertebrates 50: 105-116.

Seyfullah LJ, Beimforde C, Dal Corso J, Perrichot V, Rikkinen J, Schmidt AR. 2018. Production and preservation of resins - Past and present. Biological Reviews 93: 1684-1714. https://doi.org/ 10.1111 /brv. 12414 .

Sonibare OO, Agbaje OB, Jacob DE, Faithfull J, Hoffmann T, Foley SF. 2014. Terpenoid composition and origin of amber from the Cape York Peninsula, Australia. Australian Journal of Earth Sciences 61: 979985. https://doi.org/10.1080/08120099.2014.960897.

Sonibare OO, Hoffmann T, Foley SF. 2012. Molecular composition and chemotaxonomic aspects of Eocene amber from the Ameki Formation, Nigeria. Organic Geochemistry 51: 55-62. https://doi. org/10.1016/j.orggeochem.2012.08.003.

Stilwell JD, Langendam A, Mays C, Sutherland LJM, Arillo A, Bickel D., et al. 2020. Amber from the Triassic to Paleogene of Australia and New Zealand as exceptional preservation of poorly known terrestrial ecosystems. Scientific Reports 10: 5703. https://doi.org/ 10.1038/s41598-020-62252-z.

Stroiński A. 2007. Pochazoides szwedoi n. sp. from the East African copal (Hemiptera: Fulgoromorpha: Ricaniidae). Genus 18: 345-349.

Stroiński A, Szwedo J. 2002. An overview of Fulgoromorpha and Cicadomorpha in East African copal (Hemiptera). Denisia 4: $57-66$.

Stroiński A, Szwedo J. 2011. Yuripopoverus africanus gen. et sp. n. from East African copal (Hemiptera: Fulgoromorpha: Ricaniidae). Polish Journal of Entomology 80: 679-688. https://doi.org/ 10.2478/v10200-011-0052-x.
Sunseri T. 2007. The political ecology of the copal trade in the Tanzanian coastal hinterland, c. 1820-1905. Journal of African History 48: 201-220.

Vávra N. 2009. Amber, fossil resins, and copal-Contributions to the terminology of fossil plant resins. Denisia 26: 213-222.

Vervloet G. 1932. Le copal du Congo. Paris: Pelissier \& Frey.

Ward PS, Brady SG, Fisher BL, Schultz TR. 2010. Phylogeny and biogeography of dolichoderine ants: effects of data partitioning and relict taxa on historical inference. Systematic Biology 59: 342-362. https://doi.org/10.1093/sysbio/syq012.

Westerweel J, Roperch P, Licht A, Dupont-Nivet G, Win Z, Poblete F, et al. 2019. Burma Terrane part of the Trans-Tethyan arc during collision with India according to palaeomagnetic data. Nature Geoscience 12: 863-868. https://doi.org/10.1038/s41561-019-0443-2.

Wilson RC. 1925. The geology of the eastern railway section Port Harcourt to Enugu. Geological Survey of Nigeria Bulletin 8: 1-95.

Wunderlich J. 2004. Fossil spiders in amber and copal: Introduction, general findings and conclusions. Beiträge zur Araneologie 3: $1-329$.

Wunderlich J. 2008. Fossil and extant spiders (Araneae) - Phylogeny, diversifications, extinctions, biogeography, ecology and ethology; with descriptions of new fossils and extant taxa. Beiträge zur Araneologie 5: 1-890.

Zeuner FE, Manning FJ. 1976. A monograph on fossil bees (Hymenoptera: Apoidea). Bulletin of the British Museum of Natural History (Geology) 27: 151-268.

Zimmerman A. 1908. Der ostafrikanische Copalbaum (Trachylobium verrucosum). Der Pflanzer 4: 17-23.

Cite this article as: Bouju V, Perrichot V. 2020. A review of amber and copal occurrences in Africa and their paleontological significance, $B S G F$ - Earth Sciences Bulletin 191: 17. 